\title{
Diagnostic value of urinary pyridinoline for determining bone metastasis in patients with non-metastatic breast cancer
}

\author{
Metastaz bulunmayan meme kanserli hastalarda idrar piridinolin'in tanısal değeri
}

\author{
Zeynep Giniş', Sevilay Sezer², Nuriye Özdemir ${ }^{3}$, Fatma Uçar ${ }^{4}$, Serpil Turhan² \\ ${ }^{1}$ Dıskapı Yıldırım Beyazıt Training and Research Hospital, Biochemistry Laboratory, Ankara, Turkey \\ ${ }^{2}$ Ankara Numune Training and Research Hospital, Biochemistry Laboratory, Altındağ, Ankara, Turkey \\ ${ }^{3}$ Ankara Numune Training and Research Hospital, Medical Oncology Clinic, Altindağ, Ankara, Turkey \\ ${ }^{4}$ Etlik Yüksek ihtisas Hospital, Biochemistry Laboratory, Ankara, Turkey
}

\begin{abstract}
Objective: In this study, urinary pyridinoline (uPYR), urinary deoxypyridinoline (UDPD) and serum alkaline phosphatase (SALP) levels were measured in patients without metastatic breast cancer and the role of UPYR and UDPD as biochemical markers of bone metastases were examined during a six years follow-up.
\end{abstract}

Materials and methods: Totally, 34 patients without bone metastasis and 40 healthy individuals as a control group were included in the study.

Results: Urinary pyridinoline and UDPD levels were significantly higher in patients without bone metastasis than in normal controls $(p<0,05)$, except sALP levels. As a result of a 6 -year follow-up of patients, $20.5 \%$ had metastasis. The distribution of metastasis types was as follows: $2.9 \%$ of those patients had local, $2.9 \%$ had liver, $5.9 \%$ had lung and $8.8 \%$ had bone metastasis. The cut off value, sensitivity and specifity of UPYR was established as $47,3 \mathrm{pmol} / \mu \mathrm{mol}$ creatinin, $82 \%$ and $80 \%$ respectively. The cut off value, sensitivity and specifity of uDPD were determined as $9.53 \mathrm{pmol} / \mu \mathrm{mol}$ creatinin, $76 \%, 72 \%$ respectively.

Conclusions: This study demonstrated that measurement of urinary collagen cross-links assay may contribute to the early detection of metastatic spread to bone in breast cancer. However further studies with larger scaled groups should be performed. J Clin Exp Invest 2011; 2 (4): 420-424

Key words: Breast neoplasms, bone metastases, deoxypyridinoline, pyridinoline

\section{INTRODUCTION}

Breast cancer is the cancer of breast tissue. Worldwide, it is the most common form of cancer in females, affecting approximately 1 out of 11-12 wom-

\section{ÖZET}

Amaç: Bu çalışmada metastazı olmayan meme kanserli hastalarda idrar piridinolin, deoksipiridinolin ve serum alkalen fosfataz düzeyleri ölçüldü ve 6 yıllık takipte kemik metastazının biyokimyasal belirteçleri olarak idrar piridinolin ve deoksipiridinolinin rolü değerlendirildi.

Gereç ve yöntem: Çalışma kemik metastazı olmayan 34 hasta ve kontrol grubu olarak 40 sağlıklı bireyi içermektedir.

Bulgular: Serum ALP hariç idrar piridinolin ve deoksipiridinolin düzeyleri kemik metastazı olmayan hastalarda kontrol grubundan belirgin olarak yüksekti. 6 yıllık takip sonucunda hastaların \%20.5'da metastaz olduğu belirlendi. Metastaz tiplerinin dağılımı: \%2.9 lokal, \%2.9 karaciğer, \%5.9 akciğer ve \%8.8 kemik metastazı. Piridinolin için $43 \mathrm{pmol} / \mu \mathrm{mol}$ kreatinin cut off değerinin sensitiivtesi $\% 82$ ve spesifitesi \%80 olarak belirlendi. Deoksipiridinolin için $9.53 \mathrm{pmol} / \mu \mathrm{mol}$ kreatinin cut off değerinin sensitiivtesi $\% 76$ ve spesifitesi $\% 72$ olarak belirlendi.

Sonuç: Bu çalışma idrar çapraz bağlarının ölçümünün meme kanserinde kemiğe metastatik yayılımın erken belirlenmesine katkıda bulunabileceğini gösterdi. Ancak geniş ölçekli gruplarla ileri çalışmalar yapılmalıdır.

Anahtar kelimeler: Meme kanserleri, kemik metastazları, deoksipiridinolin, piridinolin.

en at some stage of their life in the Western world. Although significant efforts are made to achieve early detection and effective treatment, about $20 \%$ of all women with breast cancer will die from the 
disease, and it is the second most common cause of cancer deaths in women. ${ }^{1}$

Up to one-third of patients with early stage breast cancer will eventually die from the disease, and most of these ( $\sim 80 \%)$ will have bone metastases. ${ }^{2,3}$ Although a majority of these bone metastases are destructive or osteolytic, a significant percentage also causes abnormal bone formation or osteosclerotic lesions. Once tumor has metastasized to bone, the disease is incurable. Because the average survival of breast cancer patients following diagnosis of bone metastases is $24-36$ months, the morbidity of bone pain, fracture, hypercalcemia and nerve compression syndromes are longstanding. Therapeutics to treat and prevent these devastating complications of bone metastases are therefore in great demand. ${ }^{4}$

The metastases to bone causes accelerated bone resorption both from direct effects of the tumor itself and through the activation of osteoclast cells in bone via humoral and growth factors such as cytokines, platelet-derived growth factor and parathyroidrelated protein. ${ }^{5}$

Breast cancer may affect bone metabolism, producing increased bone resorption with or without an associated increase in bone formation. Bone metastases usually stimulate bone resorption more than bone formation and thus markers of bone formation, e.g. alkaline phosphatase, are not as valuable markers of disease activity as markers of bone degradation such as urinary pyridinoline (UPYR) and urinary deoxypyridinoline (UDPD). ${ }^{6}$

UPYR and UDPD is formed during the posttranslational phase of collagen synthesis and is corporated into the bone matrix as a component of collagen molecules. Whereas UPYR is widely distributed throughout the body tissues, UDPD is only found in collagen of bone and dentin. ${ }^{7,8}$

When bone resorption occurs, osteoclastic degradation of bone matrix releases UPYR and UDPD into the circulation; these compounds are than excreted in urine. Measurement of urinary elimination of these compounds may provide useful information on the change of bone resorption. ${ }^{9}$

In this study, we measured UPYR and UDPD in patients without metastatic breast cancer and examined the role of UPYR and UDPD as biochemical markers of bone metastases. We compared the results of urine UPYR, UDPD and serum alkaline phosphatase (sALP) with breast cancer cases with no known bone metastases, with control subjects. And patients were followed for six years. Further- more, the effect of menopause was investigated on levels of urine UPYR, UDPD and SALP.

\section{MATERIALS AND METHODS}

\section{Patients and study design}

As shown in Table I, thirty-four patients with histologically verified breast cancer without bone metastasis and 40 age- and menapausal-matched healthy control participated in the investigation. Healthy control subjects were ambulatory population without evidence of neoplastic or metabolic disease.

Patients with skeletal, endocrine, hepatic disease or with previous medical conditions or drug terapies that may affect bone metabolism were excluded from this study. Based on clinical, radiological and sintigraphic evidence, patients without metastatic breast cancer were selected for this study. All patients were referred from newly diagnosed and not receiving any treatment patient groups.

Written informed consent was obtained from both healthy controls and cancer patients before the collection of blood or urinary samples. The study was approved by the local ethics committee.

\section{Sample collection and assays}

Urine sample for measurement of UPYR, UDPD and creatinine was collected between 10:00 a.m. and 12:00 a.m., from fasting individuals. Specimens were divided into two aliquots, and urinary concentrations of creatinine were measured immediately after sample collection by standard laboratory methods using an autoanalyzer (Abbott, Aeroset - Texas, USA). The other aliquot was stored at $-20^{\circ} \mathrm{C}$ until analyzed.

UPYR and UDPD were assayed by automated HPLC measurements was supplied by Chromosystems Instruments and Chemical $\mathrm{GmbH}$, Munich, Germany. The intra-assay coefficients of variation for UPYR and UDPD were $3,8 \%$ and $5,9 \%$, respectively, and for inter-assay variation were $5,1 \%$ and $8,9 \%$, respectively. The values obtained were corrected for creatinine excretion and the data were expressed pmol PYR (or DPD) per $\mu \mathrm{mol}$ creatinin.

Blood samples for measurement of sALP were collected from patients who had fasted overnight, centrifuged and assayed by standard laboratory methods (Abbott, Aeroset - Texas, USA)

\section{Statistical analysis}

Results having normal distribution are reported as mean $\pm \mathrm{SD}$. Kolmogorov-Smirnov was used to 
check the normal distribution of all parameters. The statistical significance of the differences between the means of uDPD/Cre, u uPYR /Cre ratios and sALP of premenopausal and postmenopausal patients without bone metastases and healthy controls were assessed by Mann-Whitney $U$ test. The statistical significance of the differences between the means of uDPD/Cre, uPYR/Cre ratios and SALP of patients and control groups was assessed by Independent Student's T test. Values of $p$ less than 0.05 were considered as significant. The ROC curve was used to evaluate the diagnostic values of the parameters

\section{RESULTS}

In patients without bone metastases and healthy controls, uDPD/Cre, uPYR /Cre ratios and SALP did not differ in premenopausal and postmenopausal patients $(p>0,05)$ (Table 1$)$.

Table 1. Age and laboratory parameters in normal controls and cancer patients according to menopausal status

\begin{tabular}{lcccccc}
\hline & \multicolumn{2}{c}{ Controls } & \multicolumn{3}{c}{ Patients } \\
\cline { 2 - 6 } & $\begin{array}{c}\text { Premenopausal } \\
\mathrm{n}=25\end{array}$ & $\begin{array}{c}\text { Postmenopausal } \\
\mathrm{n}=15\end{array}$ & $\mathrm{P}$ & $\begin{array}{c}\text { Premenopausal } \\
\mathrm{n}=12\end{array}$ & $\begin{array}{c}\text { Postmenopausal } \\
\mathrm{n}=22\end{array}$ & $\mathrm{P}$ \\
\hline Age, years & $34 \pm 6.3$ & $55 \pm 5.4$ & $<0.05$ & $41 \pm 9.8$ & $61 \pm 8.9$ & $<0.05$ \\
uPYR $(\mathrm{pmol} / \mathrm{\mu mol})$ & $40.17 \pm 1.91$ & $38.75 \pm 1.92$ & $>0.05$ & $59.83 \pm 4.88$ & $60.78 \pm 4.25$ & $>0.05$ \\
uDPD $(\mathrm{pmol} / \mathrm{\mu mol})$ & $9.59 \pm 0.63$ & $8.86 \pm 0.61$ & $>0.05$ & $13.82 \pm 1.37$ & $13.36 \pm 0.90$ & $>0.05$ \\
sALP $(\mathrm{U} / \mathrm{L})$ & $30.62 \pm 1.57$ & $27.19 \pm 1.42$ & $>0.05$ & $21.76 \pm 3.11$ & $27.90 \pm 2.74$ & $>0.05$ \\
\hline
\end{tabular}

UPYR and UDPD levels were significantly higher in patients without bone metastases than in normal controls $(p<0,05)$. But In patients without bone metastases and healthy controls SALP did not differ (Table 2).

Table 2. Urinary pyridinoline/creatinin and deoxypyridinoline/creatinin and serum alkaline phosphatase levels in patients without bone metastases and healthy controls

\begin{tabular}{|c|c|c|c|}
\hline & $\begin{array}{l}\text { Patients } \\
(n=34)\end{array}$ & $\begin{array}{l}\text { Controls } \\
(n=40)\end{array}$ & $\mathrm{p}$ \\
\hline $\begin{array}{l}\text { Urinary pyridinoline/ } \\
\text { Creatinin }(\mathrm{pmol} / \mu \mathrm{mol})\end{array}$ & $60.45 \pm 18.68$ & $39.64 \pm 8.75$ & $<0.001$ \\
\hline $\begin{array}{l}\text { Urinary deoxypyridinoline/ } \\
\text { Creatinin }(\mathrm{pmol} / \mu \mathrm{mol})\end{array}$ & $13.532 \pm 4.35$ & $9.31 \pm 2.91$ & $<0.001$ \\
\hline $\begin{array}{l}\text { Serum alkaline } \\
\text { phosphatase (IU/L) }\end{array}$ & $25.73 \pm 12.38$ & $29.33 \pm 7.20$ & NS \\
\hline
\end{tabular}

NS: Not significant

After a 6-year follow-up of patients, $5.9 \%$ had died $(n=2), 20.5 \%$ metastasis patients are alive yet. The distribution of metastasis types were as follows: $2.9 \%$ of those patients local $(n=1), 2.9 \%$ liver $(n=1)$, $5.9 \%$ lung $(n=2)$ and $8.8 \%$ bone metastasis $(n=3)$.

The cut off value, sensitivity and specifity of uPYR were established $47,3 \mathrm{pmol} / \mu \mathrm{mol}$ creatinin, $82 \%$ and $80 \%$ respectively. The cut off value, sensitivity and specifity of UDPD were determined 9,53 $\mathrm{pmol} / \mu \mathrm{mol}$ creatinin, $76 \%, 72 \%$ respectively. Area under the curve of UPYR, UDPD and sALP were found $0.84,0.79$ and 0.35 respectively (Figure 1 ).

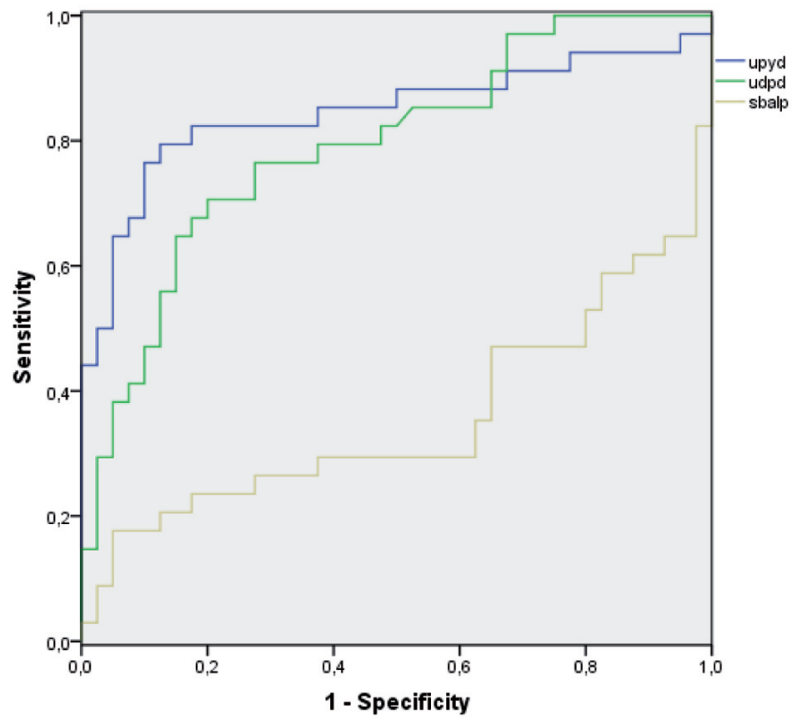

Figure 1. Receiver operating characteristic curves of UPYR, UDPD and SALP in the diagnosis of bone metastasis.

\section{DISCUSSION}

Bone metastasis is present in $69 \%$ of patients with terminal breast cancer. It is often difficult to detect early bone metastasis and to assess their therapeu- 
tic responses solely based on bone scans and bone x-rays. ${ }^{9}$

In this study, we measured urine UPYR, UDPD and SALP in patients without metastatic breast cancer and examined the role of UPYR and UDPD as a biochemical marker of bone metastasis. We compared the levels of UPYR and UDPD and SALP with breast cancer cases with no known bone metastasis, and a group of control subjects. Furthermore, the effect of menopause was investigated on levels of UPYR, UDPD and SALP and all patients were followed-up for six years.

Bone metastasis usually stimulate bone resorption more than bone formation and thus markers of bone formation, e.g. alkaline phosphatase (except prostat cancers), are not as valuable markers of disease activity as markers of bone degredation such as UPYR and UDPD. Some researchers has reported that the sensitivity of markers of bone resorption was $50-80 \%$. $^{6,10}$ Bombardieri et all. showed that sALP was not as valuable markers of disease activity as markers of bone degradation in their study. ${ }^{11}$

Several works have shown that assays of UPYR and UDPD may be valuable markers of bone resorption in a small series of patients with bone metastasis. Hiraide et al. and Walne et al. have reported elevated values of UPYR and UDPD in patients with bone metastasis compared with normal control groups. ${ }^{12,13}$ In this study, the UPYR and UDPD values for patients without bone metastasis were significantly higher than those of healthy women.

The effect of menopause on UPYR and UDPD has been assessed by several studies. Uebelhart et al. ${ }^{14}$ showed that a significiant increase of UPYR and UDPD in postmenopausal healthy women compared to age-matched premenopausal women. Hiraide et al. ${ }^{12}$ also showed significiantly higher values after menopause. According to these results, menopause effect should be taken into account in the diagnosis of bone metastasis by UPYR and UDPD analysis.

Although age-related changes of UPYR and UDPD values were noted in some reports, which showed significiant increase in children and postmenopausal women, Hou MF et al. ${ }^{9}$ found that there was no significiant relationship between urine $\mathrm{Dpd} / \mathrm{Cre}$ ratios and the menopausal status. This suggests that the bone destruction induced by the menopause is less than that caused by cancer metastasis. This study also showed that there were no different values of UPYR, UDPD and SALP between postmenopausal healthy women and age-matched premenopausal women.
Unexpectedly some researchers found higher levels of UPYR and UDPD in breast cancer patients without bone metastases compared to control groups' values. , $16,17,18$ We have also obtained similar results. Despite a negative radiological or radioistopical skeletal survey, there are different explanations about high levels of UPYD and UDPD in patients without metastatic bone disorders. First, the invading neoplastic disease might directly induce the release of pyridinium cross-links from extraosseous tissue, such as tendons, cartilage or blood vessels. Thus, excretion in the urine of piridinyum cross-links increased and urinary PYR / DPD ratio altered. Catabolic events associated with the neoplastic disease might stimulate bone resorption throughout the skeleton. This theory is supported by the fact that mediators of tumor cachexia, such as tumor necrosis factor- $\alpha$ and interleukin -1 and -6 are also considered potent stimulators of osteoclast activity. Subclinical osteolysis could also contribute to the elevated levels of urinary crosslinks. ${ }^{8}$

Pecherstorfer et al. ${ }^{8}$ reported that from a group of 55 individuals without bone metastasis at the beginning of the follow-up, only 2 of them had developed bone metastasis. We also followed our patients. After a 6-year follow-up of patients, $5.9 \%$ had died $(n=2), 2.9 \%$ of those patients had local metastasis $(n=1), 2.9 \%$ had liver metastasis $(n=1), 5.9 \%$ had lung metastasis $(n=2)$ and $8.8 \%$ had bone metastasis $(n=3)$.

The efficacy of UPYR, UDPD to discriminate between patients without neoplastic bone involvement and healthy group was assessed by ROC analysis. Pecherstorfer et al. ${ }^{8}$ found that the urinary pyridinium cross-links were obviously most effective in predicting the absence or evidence of metastatic bone

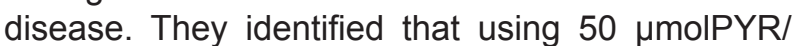
mol creatinine as the cut-off level, the sensitivity of UPYR to predict bone metastases was $88.7 \%$, and the specificity was $41.8 \%$. Walls et al. showed that the sensitivity of UPYR was $80 \%$, the specificity was $93 \%$ by using $70 \mu \mathrm{molPYR} / \mathrm{mol}$ creatinine as the cut-off level.

We have demonstrated that the area under the ROC curve was 0.84 for UPYR, 0.79 for uDPD. So, the best diagnostic efficiency by comparing the area under the curve was provided by UPYR followed by UDPD and SALP. The cut off value, sensitivity and specificity of PYR were established $47.3 \mathrm{pmol} / \mu \mathrm{mol}$ creatinin, $82 \%$ and $80 \%$ respectively. The cut off value, sensitivity and specificity of UDPD were determined $9.53 \mathrm{pmol} / \mu \mathrm{mol}$ creatinin, 76\%, 72\% respectively. As mentioned above, because of the low specificity of UPYR was the release of pyridinium 
cross-links from extraosseous tissues after the invasion and subclinical osteolysis. ${ }^{8}$ The higher sensitivity of UPYR was considered to be due to the fact that the concentration of UDPD was about a quarter that of UPYR, so that the error in measuring UDPD assay became larger. ${ }^{12}$

In conclusion, this study revealed that measurement of UPYR and UDPD assays may contribute to the early detection of metastatic spread to bone in breast cancer patients. The high UPYR and UDPD level may be an early sign of occult metastases in patients with no bone metastasis assessed by scintigraphic techniques.

Because survival after diagnosis of bone metastases is relatively short for patients with breast tumors, methods are needed to predict skeletal complications in a shorter timescale than is possible with current imaging methods. From the results of our current study, the use of bone marker data may make a major contribution to this need by identifying those patients at highest risk who warrant the highest priority for intervention to prevent skeletal complications. But longitudinal studies should be performed to evaluate whether these parameters might be useful in monitoring progression or remission of neoplastic bone disease.

\section{REFERENCES}

1. Ferlay J, Bray F, Pisani P, et al. Globocan 2002: Cancer Incidence, Mortality and Prevalence Worldwide,Version 2.0: IARC CancerBase no.5, Lyon, IARCPress, 2004.

2. Coleman RE, Rubens RD. The clinical course of bone metastases from breast cancer. $\mathrm{Br} \mathrm{J}$ Cancer 1987; 55(1):61-6.

3. Roodman G.D. Mechanisms of Bone Metastasis. N Engl J Med 2004; 50(12):1655-64.

4. Padalecki SS, Guise TA. The role of bisphosphonates in breast cancer: Actions of bisphosphonates in animal models of breast cancer. Breast Cancer Resch 2002;4:35-41.

5. Demers LM. Biochemical markers in the management of patients with metastatic bone disease. Clin Chem 2002;45(8): 1131-2.

6. Walls J, Assiri A, Howell A, et al. Measurement of urinary collagen cross-links indicate response to therapy in patients with breast cancer and bone metastases. Br J Cancer 1999; 80(8):1265-70.

7. Fohr B, Dunstan CR, Seibel MJ. Clinical review 165: Markers of bone remodeling in metastatic bone disease. J Clin Endocrinol Metab 2003; 88(11):5059-75

8. Pecherstorfer M, Zimmer-Roth I, Schilling T, et al. The diagnostic value of urinary pyridinium cross-links of collagen, serum total alkaline phosphatase, and urinary calcium excretion in neoplastic bone disease. $\mathrm{J}$ Clin Endocrinol Metab 1995; 80:97-103.

9. Hou MF, Lin SB, Yuan SS, et al. Diagnostic value of urine deoxypyridinoline for detecting bone metastases in breast cancer patients. Ann Clin Lab Sci 2003; 33(1):55-61.

10. Koizumi M, Ogata E. Bone metabolic markers as gauges of metastasis to bone: a review. Ann Nucl Med 2002; 16(3):161-8.

11. Bombardieri E, Martinetti A, Miceli R, et al. Can bone metabolism markers be adopted as an alternative to scintigraphic imaging in monitoring bone metastases from breast cancer? Eur J Nucl Med 1997; 24:134955

12. Hiraide H, Okamura S, Hayashi T, Nishida M, Tamaki $\mathrm{K}$, Tamakuma S. The Urinary Excretion of Pyridinium Cross-links as Markers of Bone Metastasis in Breast Cancer. Breast Cancer 1994; 30;1(2):103-8.

13. Walne AJ, Jenkins PJ, James IT, et al. Pyridinium crosslinks in the monitoring of patients with bone metastases from carcinoma of the breast. Clin Oncol (R Coll Radiol). 1997; 9(1):30-4.

14. Uebelhart D, Schlemmer A, Johansen JS, Gineyts E, Christiansen C, Delmas PD. Effect of menopause and hormone replacement therapy on the urinary excretion of pyridinium cross-links. J Clin Endocrinol Metab. 1991;72(2):367-73.

15. Shimozuma K, Sonoo H, Fukunaga M, et al. Biochemical markers of bone turnover in breast cancer patients with bone metastases: a preliminary report. J Clin Oncol. 1999; 29(1):16-22

16. Lipton A, Demers LM; Daniloff $Y$, et al. Increased urinary excretion of pyridinium cross-links in cancer patients. Clin Chem 1993;39(4):614-18

17. Dane F, Turk HM, Sevinç A, Büyükberber S, Camci C, Tarakcioglu M. Markers of bone turnover in patients with lung cancer. J Natl Med Assoc 2008;100(4):425-8.

18. Brown JE, Cook RJ, Major P, et al. Bone turnover markers as predictors of skeletal complications in prostate cancer, lung cancer, and other solid tumors. J National Cancer Institute 2005; 97(1): 59-69. 